\title{
Collocations in English and Arabic: A Comparative Study
}

\author{
Khalil Hasan Nofal ${ }^{1}$ \\ ${ }^{1}$ Department of English, Language Centre Philadelphia University, Jordan \\ Correspondence: Khalil Hasan Nofal, Department of English, Language Centre Philadelphia University, Jordan. \\ E-mail: nofalk48@yahoo.com
}

Received: March 28, 2012

Accepted: July 25, $2012 \quad$ Online Published: August 21, 2012

doi:10.5539/ells.v2n3p75

URL: http://dx.doi.org/10.5539/ells.v2n3p75

\begin{abstract}
In this paper, an attempt is made to study the term "collocation" as the habitual association between words. It incorporates a fairly detailed analysis of collocation in both English and Arabic. A lot of literature has been written on collocation; yet collocation in both English and Arabic and its relation to lexicography, translation and interpretation in addition to teaching/learning process gained little or even no attention from specialists and scholars. The purpose of this paper is to focus on this important area in an attempt to bring out the nature and significance of collocation and its relation to the above mentioned points. The paper concludes with some remarks and recommendations that could enhance the process of translation and interpretation as well as teaching/learning process. These remarks, findings and recommendation, if best employed, could enhance the quality of teaching, learning and interpreting collocations. Finally, it is hoped that this piece of work will bridge a gap in interpretation, teaching and learning on the one hand, and will motivate further research into other important areas in English and Arabic, on the other.
\end{abstract}

Keywords: collocation, idioms, grammatical collocations, lexical collocations, open collocations, restricted collocations, bound collocations

\section{Introduction}

Through the researcher's point of view, as a school supervisor of English at Educational Development Centre UNRWA/UNESCO-Jordan, General Education Specialist (English)-Headquarter-UNRWA, and Head/Department of English-Philadelphia University-Jordan, collocation in particular is not appropriately touched or handled in the curriculum. Besides, most of English and Arabic dictionaries do not handle this issue. Both English and Arabic dictionaries deal with idioms but not with collocations. Moreover, the interpreter cannot capture a collocation in the SL if he or she is not capable of calling up its counterpart in the TL. The interpreter's failure in such an endeavor usually results in his adoption of strategies of lexical simplification, namely reduction, synonymy, compensation, paraphrase and transfer. Therefore, unless such collocation patterns become part of the memory bank of the student, interpreter and translator, communication is certainly doomed to fail. Generally speaking, this failure is a direct consequence of the language teachers' or instructors' tendency to teach words individually rather than collocationally.

Put differently, teaching/learning process in general and interpretation/translation teaching in particular can greatly profit from the study of collocation. The interpreter's knowledge of paradigmatic relations such as synonymy, antonym, hyponymy, etc, should be coupled with a competent syntagamatic repertoire in such a way that functionalizes and idiomaticizes their phraseology. The often-heard complaint that a translation does not sound English, despite it having good wording and syntax, undoubtedly ensues from a deficiency in the area of collocation in particular and multi-word units in general. (The researcher got this fact through meeting some students, interpreters/translators and instructors at some universities in Jordan.) Prospective interpreters should, therefore, undergo extensive training that takes collocation as a major concern, and so should the teachers of both Arabic and English. Besides, the syllabus designers should take collocation into consideration, attracting L2 learners' attention to the fact that there are collocational divergences between L1 and L2. Finally collocations as opposed to idioms are not given due attention by lexicographers.

It has been emphasized by Fakhouri (1995) that "collocations can be an area where students err frequently in the process of translation and interpretation. Such errors may be due to different factors: the first factor relates to the lack of bilingual dictionaries on collocation. The second deals with the unpredictability of such collocations in 
the target language. The third factor involves the cultural and linguistic differences between the source language (SL) and the target language (TL). Finally, some errors are related to the process of learning vocabulary that encompasses semantic collocations and structural collocation". (p.1)

\section{The Concept of Collocation}

Collocation is essentially a lexical relation and not subject to rules but to tendencies. In Firth's original insight (1968), collocation is "the company that words keep" or "actual words in habitual company" (p.182). Firth attached enough importance to this "level of meaning" to propose setting up a separate collocational level of analysis of language, in addition to situational, syntactic, phonological and other levels. Halliday (1966) formalized the concept of collocation but rejected Firth's idea of separate levels of collocation. In Halliday's systemic theory, grammar and lexis are two distinct but interrelated levels of linguistic form, each level having its own syntagamatic and paradigmatic relations: structures and systems in grammar, collocations and sets in lexis. Lyons (1966) maintains that it seems that a rigorous application of Firth's contextual theory of meaning analysis of the patterns of co-occurrence of actual words without consideration of their semantic compatibility and the sense relations between them is not enough, or rather" does not provide us with a complete theory of semantics" (p.299).

Mitchell (1965) defines collocation as an association of roots or potential lexical meanings rather than actual words; further "a linguistic item or class of items is meaningful not because of inherit properties of its own but because of the contrastive or differential relationships it develops with other items or classes. Meaning is much less in the name than in the network of relevant differential relationships" (p.143). However, Mitchell also stressed the "on-going" nature of collocations, the fact that they can cut across sentence boundaries, underlining the persistently syntagamatic nature of Firthan or "lexical" approach to linguistic analysis.

In contrast, arising out of transformational grammar there developed what Lehrer (1974) terms the "semantic hypothesis" which claims that co-occurrence restrictions are the result of the meaning of the lexical items and that collocations are reflection of this fact (p.176). "The generativist view of co-occurrence was that" selection restrictions do not have independent status in semantic analysis but are predictable from the meanings of the lexical items" (ibid. 180).

Standard theories, following Chomsky, argued that selection restrictions were essentially syntactic in nature and should be assigned to the syntactic component. However, extended standard theories drew attention to the degree of arbitrariness apparent in such collocations as "addled + eggs/brains" and "rancid + bacon/ butter" See palmer (1981, p.77).

For Benson (1986) collocation is "a group of words that occurs repeatedly i.e. recurs, in a language" (p.61). Now it would not be out of place to talk about collocation in detail taking into consideration some great figures.

Porzig (1930) argued for the recognition of the importance of syntagamatic relations between "bite" and "teeth", "bark" and "dog", "blond" and "hair". In a slightly different way Firth argued that "You shall know a word by the company it keeps" (1957, pp. 194-195; 1968, p.179). His famous examples show that part of the meaning of the word "ass" can be by collocation:

1. An ass like Bagson might easily do that.

2. He is an ass.

3. You silly ass!

4. Don't be an ass!

One of the meaning of "ass" is its habitual collocation or association with an immediately preceding "you silly", and with other phrases of address or of personal reference. There are only limited possibilities of collocation with preceding adjectives among which the commonest are "silly", "obstinate", "stupid", "awful" and occasionally "egregious". For Firth this keeping company, which he called collocation, was part of the meaning of a word.

It must be pointed out that "meaning by collection is not at all the same thing as contextual meaning, which is the functional relation of the sentence to the processes of a context of situation in the context of nature". See Firth (1957, pp.194-195; 1968, p.179). Firth gives the following example: "in the language of Lear's Limericks, "man" is generally preceded by "old", never by "young". Person is collocated with "old" and "young".

As we have seen above, meaning was to be found in the context of situation and all other levels of analysis as well. It is obvious that by looking at the linguistic context of words we distinguish between different meanings. Nida (1964, p.98) for example distinguished the use of chair in: 
5. sat in a chair

6. the baby's high-chair

7. the chair of philosophy

8. has accepted a university chair

9. chairman of the meeting

10. will chair the meeting

11. the electric chair

12. condemned to the chair

These are clearly in pairs, giving four different meanings of the word. The most important step is to find substitutes for "chair" may be used in these phrases without introducing a different referent. Nida argued that the criterion for determining whether the referent is the same or different is reaction of the native speaker of the language, i.e. whether he insists that in the substitution of another form one is "saying the same thing but in different words", or that one is saying something different. It is equally possible to say of a particular event "he sat in the chair" or "he sat in a piece of furniture". Stylistically these two phrases are different, but they may be employed to refer to precisely the same event.

The substitutions employed in this type of semantic analysis are not the same as are required in formal analysis. For example, we would not use the substitute "baby's high piece of furniture", just because in one instance piece of furniture was a substitute for "chair". However one can speak about "the baby's high chair" as a piece of furniture. On the other hand, chair in example 7 and example 8 above is never substituted for by "piece of furniture", but rather by "teaching position" or by "post". In example 9 and example 10 above one may speak of presiding over the meeting, and in example 11 and example 12, a typical substitute would be "death" or "execution" e.g. "condemned to death".

Collocation is not simply a matter of association of ideas. For, although milk is white, we should not often say "white milk", though the expression "white paint" is common enough. Some of Porzig's examples seem more concerned with association of ideas. How often is "lick" actually collocated with "tongue"? More importantly, although collocation is very largely determined by meaning, it is sometimes idiosyncratic and cannot easily be predicted in terms of the meaning of the associated words. One example is Porzig's "blond" with "hair". For we should not talk about "a blond door" or "blond dress", even if their colors are exactly like that of blond hair. Similarly "rancid" occurs only with "bacon" and "butter", and "addled" with "brains" and "eggs" in spite of the fact that English has the terms "rotten" and "bad" and that "milk" never collocates with "rancid" but only with "sour ". Similar examples are found in Arabic.

\section{3. خلف الناقة \\ xilf-u ?al-nāqa}

(the breast of the she-camel)

$$
\begin{aligned}
& \text { 14. ضرع البقرة } \\
& \text { đir?-u ?al-baqara }
\end{aligned}
$$

(the breast of the cow)

15. ثدي المر أه

Өady-u ?al-mar?a

(the breast of the woman)

"xilf", "đir?" and "Oady" are synonymous: they mean breast. But they are collocational restrictions of their usage so that they co-occur respectively with "nāqa" "she camel", "baqara", (cow) and "mar?a", (woman ) as in example13, 14, 15 above (Al-Tha'alibi, p.74).

From Palmer's famous examples (1981), we can see "pretty child" and "buxom neighbor" would normally refer to females; here it is relevant to point out we should not normally say "pretty boy" or "buxom man" though "pretty girl" and "buxom woman" are quite normal (p.143). Similarly, we permit "pregnant woman" and "pregnant horse" but not "pregnant man" (Kats \& Fodor, 1963, pp. 170-210). It would be a mistake to draw a clear distinguishing line between those collocations that are predictable from the meanings of the word that co-occur and those that are not. It could be argued that "rancid" is to be defined in terms of the very specific, 
unpleasant taste associated with "butter" and "bacon" that is "pretty" describes only a feminine kind of beauty. There is some plausibility in accounting for "dogs bark", "cats mew" in terms of the kind of noise made, since "bark" can be used by other animals, e.g squirrels. This fact is also found in Arabic.

16. صياح الديك

şiyāh-u ?al-dīk.

(the cry of cock)

خوار البقرة .17

xiwār-u ?al-baqara

(the lowlmoo of the cow)

18. ثغاء الحمل

Oughū?-u ?al-hamal

(the bleat of the sheep)

19. عواء الذئب

?uwā?-u ?al-ði? b

(the howl of the wolf)

20. نباح الكلب

Nubāh-u ?al-kalb

(the bark of the dog)

21. زئير الأسد

za?̄ir-u ?al-?asad

(the roar of the lion)

22. نهيق الحمار

Nahīq-u ?al-himār.

23. صهيل الفرس

şahîl-u ?al-faras

(the neigh of the horse) (Al-Tha'alibi, pp. 138-140).

This characteristic of language is found in an extreme form in collective words in both English and Arabic:

24. flock of sheep.

25 . herd of cows.

26. school of whales.

27. pride of lions.

28. chattering of magpies.

29. exaltation of larks.

30. جيل من الناس

jīl-un min ?al-nās.

generation/gathering of people

31. كوكبة من الفرسان

kawkabat-un min ?al-fursān.

troop/group of horsemen

32. حزقة من الغلمان

ћizqat-un min? al-ghilmān.

party/group of children

33. لمَّة من النساء 
lummat-un min ?al-nisā? .

party/group of women

34. رعيل من الخيل

ra؟1̄-un min?al-xayl

party/group of horses

35. قطيع من الغنم

qați?-un min ?al-ghanam.

flock of sheep

36. سرب من الظباء

sirb-un min ?al-ð。 ibā?

school of deer

37. عصابة من الطبر

؟sābat-un min ?al-țayr

school/band of birds (Al-Tha'alibi, p.143).

From the above examples, we can see that it is difficult to see any semantic explanation for the use of the collective terms. The only difference for example between "herd" and "flock" is that one is used with "cow" and the other with "sheep". Similarly in Arabic "qațị? un" is used with "ghanam" and "sirb "with "ðibā?".

Words may have more specific meaning in particular collocations. Thus we can speak of "abnormal" or "exceptional" weather if we have a heat wave in November, but an "exceptional child" is not an "abnormal child", "exceptional" being used for greater than usual ability and "abnormal "to relate to some kind of defect. (Palmer, 1981, p.77)

\section{Collocations and Idioms}

An idiom is the term used to refer to a sequence of lexical items, semantically and syntactically restricted, functioning as a single indivisible unit. Thus, idioms are sequences of words whose meaning cannot be predicted from the meanings of the words themselves. Familiar examples from both English and Arabic:

38. Kick the bucket.

39. Fly oft the handle.

40. Spill the beans.

41. It's raining cats and dogs.

42. بلغ السيل الزبى

balagha ?al-sayl-u ?al-zubā.

to become unbearable

43. عاد بخفي حنين

؟āda bi-xuffayy hunayn.

to come back empty handed

44. أطلق ساقيه للاريح

?aţlaqua sāqayhi lil-rīh.

to run away head over heels

The point is clear if we contrast kick the table, fly off the roof, spill the coffee and so on. Semantically, idioms are single units, but they are not single grammatical units, for there is not past tense* kick the bucketed, for example.

Although an idiom is semantically like a single word, it does not function like one. Thus, we will not have a past tense kick* the bucketed. Instead it functions as a normal sequence of grammatical words, so that the past tense form is kicked the bucket. But there are a number of grammatical restrictions. A large number of idioms contain a verb and a noun, but although the verb may be placed in the past time, the number of the noun can never be changed. We have "spill the beans" but not "spill the bean" and equally there is no "fly off the handles", or "kick 
the buckets". There are also syntactic restrictions: some idioms have passives but others do not. "The beans have been spilled" is all right, but "the bucket was kicked" is not. Similarly the idiomatic expression "it's raining cats" nor and dogs" does not permit "it's raining dogs and cats", "it's raining a cat" nor "it's raining a cat and a dog". For further discussion see Lyons (1968, chapter 5).

It is not out of place to state some other definitions of some great figures. For Mitchell (1971), an idiom is "immutable in the sense that its parts are unproductive in relation to the whole in terms of the normal operational processes of substitution, transposition, expansion, etc" (p.59). For Cruse (1986) an idiom is "an expression whose meaning cannot be inferred from the meaning of its parts" (p.37).

Arabic idioms can be characterized as follows:

1. An idiom is a semantically single indivisible unit whose meaning can't be predicted from the meanings of the individual words themselves.

2. Adaptation, substitution and omission are not allowed. In the idiomatic expression (في ذمة الهة fimat-i ?allah), the word "ðima" can't be changed into plural form "ðimam". Similarly the word "?allah" can't be substituted by the word "?al-rab" which means the same. Besides, we can't omit any individual word.

3. Proposing and postponing are not allowed. e.g على قدم وساق ع a ala qadam-in wa-šāq-in is all right but ؟ala şāq-in wa -qadam-in is not allowed. Similarly أكل الدهر عليه وشرب و شرب الدهر عليهو واكل šaribā ?al-dahr-u ?alayhi wa?akal is odd.

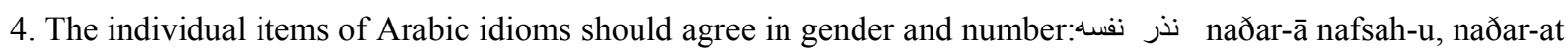
nafsah-ā, naðar-tu nafsī, naðarnā ?anfusanā.

Collocation, on the other hand, "is a lexicological term used by linguists to refer to the habitual co-occurrence of individual lexical items" (Fakhouri, 1995, p.8). For instance, the word "auspicious" collocates with "alphabet" or with "occasion" as in "an auspicious occasion. Cowie (1981) defines a collocation as "a composite unit which permits the substitutability of items for at least one of its constituent elements" (p.224). Cowie uses the term "composite unit" to subsume both collocation and idioms. How, then, can we distinguish between collocations and idioms? Bolinger (1976) states the difference in conventional terms: "idioms are different from collocations in that they have meanings that cannot be predicted from the meanings of the parts" (p.5). That is to say, one cannot infer the meaning of the idiom from the meaning of its parts, where the parts of the idiom constitute one semantic unit. On the other hand, in collocation each lexical item constitutes a semantic unit. Another difference relates to the fact that the meaning of an idiom can be replaced by one lexical item, whereas in collocation, this is not possible. Consider the following examples from both English and Arabic:

Idiom: kick the bucket can be replaced by “die” قاب قوسين أو أدنى "qāba qawsayni ?wa ?adnā” can be replaced by "Wašikan".

Collocation: "fish and chips" cannot be replaced by one lexical item nor can the Arabic collocation إنهمر المطر ?inhamara ?almațaru ?al- ghazīr-u” be replaced by one item.

This is to say, while an idiom is a semantic unit, a collocation is a formal one.

According to Cruse (1986), the essential difference is that an idiom is a "lexical complex which is semantically simplex"; while in collocation each lexical constituent is also a semantic constituent (p.37). In other words, a collocation is semantically complex. A collocation may be idiom-like in respect of constraints on the combinability of constituents, but is phrase-like in semantic structure. As Ballinger (1976) puts it, "A collocation may involve normal senses of all the words in a string but without the easy possibility of substituting some other with the same meaning" (p.6).

\section{Collocations in English}

Many linguists have addressed collocations in English. They have come up with similar definitions and categories, but they may differ in their focus. Robins (1964) defines collocations as "the habitual association of a word in a language with other particular words in sentences" (p.66). He argues about two types of collocations: the first type refers to situational meaning of words concerned as in "white coffee", "black coffee", "white race" and "white wine" where these colors are not used with reference to their referents. The other type refers to the referential meaning of words as in "dark night" where one meaning of "night" is its collectability with "dark" and vice versa. Palmer (1981) conceives of three types of restrictions on collocation: The first refers to those collocations "which are based wholly on the meaning of the items, as in the unlikely "green cow" (p.79). The second deals with items "that are based on range word maybe used with a whole set of words that have some semantic features in common, as in "the rhododendron passed away" and equally of "the pretty boy". Thirdly, 
some restriction are collocational in the strictest sense, involving neither meaning nor range, as "addled" with "eggs" and "brains". For further discussion on collocation restrictions, please refer to Allerton's (1984) Three (or four) Levels of Word Co-occurrence Restriction (pp.17-40).

Firth (1957) in his later work introduces the notes of collocation as a part of his theory of meaning (pp. 196-197). It is at the so-called collocation level of analysis, intermediate between the situational and the grammatical with lexical meaning; i.e. with that part of the meaning of lexemes which depends, not upon their functions in particular context of situation, but upon their tendency to co-occur in text. He tells us, for example, that one meaning of "night" is its collectability with "dark" and of "dark" collocation with "night". Meaning by collocation is an abstraction at the syntagamatic level and is not directly concerned with the conceptual or idea approach to the meaning of words. One of the meanings of "night" is its collectability with "dark", and of "dark" with "night".

Newmark (1981) deals with collocations on syntactic grounds. He, therefore, categorizes collocation as either paradigmatic or syntagamatic (p.114). Paradigmatic categories are based on well-established hierarchies such as kinship as in "father and sons", colours as in "emerald is a bright green", scientific taxonomies and institutional hierarchies" where the elements of the culture for each language often have their own distinct linguistic likeness. Newmark (1981) lists seven groups of syntagamatic collocation (p.118). He maintains that only there happen to be the commonest:

1) adjective and noun e.g. "heavy labour"

2) noun and noun e.g. "nerve cell"

3) verb and noun e.g. pay a visit (Newmark, 1988, p.212)

Benson, M. (1986) says that collocation (a group of words that occurs repeatedly) can be divided into grammatical collocations and lexical collocation. See (Hill, J., 1999; Williams, B., 2005).

\subsection{Grammatical Collocations}

Benson, M. (1986) defines grammatical collocation as "a dominant word (verb, noun, adjective) followed by a grammatical word, typically a preposition". Examples are:

1) Verb-preposition combination (prepositional verbs): these are combination of a verb and preposition: abide by, abstain from, account for, aim at, and accuse (somebody) of, look after, and struggle for.

2) Noun-preposition combination: access to, accusation against, administration for, analogy between (to, with).

3) Adjective-preposition combination: absent from, accountable to (with) answerable for (to) and -ed participle adjectives, -ing participle adjectives: accompanied by, corresponding to.

4) Verb-participle combination (phrase verbs). Some verbs need to be followed by specific adverbial particles. These are called "phrasal verbs" whose meaning is different from the meaning of the separate constituents of the verb and the particle. Arts F. and Arts J. (1986) defines phrasal verbs as "combination of a verb and a number of a closed set of adverbs: about, by, down, along, around, aside, back among others: bring about, catch on, make up, call up, set out, step down" (p.43). It is worth noting that in transitive phrase verbs, the particle (adverb) can generally occur before and after the direct object. Compare:

Did you make up this story?

* Did you make this story up?

How do you account for this phenomenon's?

* How do you account this phenomenon for?

The meanings of the grammatical collocations are more or less inferable from the meanings of their parts, even though the prepositions in the collocations are not predictable.

\subsection{Lexical Collocations}

Lexical collocations contain no subordinate element; they usually consist of two equal lexical components. The major types of lexical collocations are:

1) Noun-verb combinations: adjectives modify, bells ring, bees buzz (sting, swarm) birds chirp (fly, sing), blood circulates (flows).

2) Adjective-noun combinations: a confirmed bachelor, a pitched battle, pure chance, keen competition, grave concern, sincere condolences. 
3) Verb-noun combinations:

a. Verbs denoting creation-nouns: compile a dictionary, make an impression, compose music, and inflict a wound.

b. Verbs denoting activation - nouns: set an alarm, fly a kite, launch a missile, wind a watch.

c. Verbs denoting eradication and/or nullification-nouns: reject an appeal, recall a bid, lift a blockade, invalidate a clause, break a code, eliminate a competitor.

4) Adverb-verb combination: Adverbs usually occur finally, but if we add a special impression or emphasis, we move it before the verb: strongly suggest, barely see, thoroughly plan, hardly speak, deliberately attempt.

5) Adverb-adjective combination: These are used to emphasize purpose, or when we intend to add a strong feeling or a special kind of behavior to adjectives: totally acceptable (different), extremely odd, completely useless, successfully (barely) finished (noticed).

Finally, Obana (1993) distinguishes two types of collocations: structural and semantic. He argues that structural collocation is a type of lexical cohesion by which two lexical items are structurally related because the feature of one accords with that of the other. For example: "die" can occur with "man" as in "the man died" but not with "spoon" as in "The spoon died". The word "die" acquires a certain semantic feature in "man" that is "+alive" which the word "spoon" lacks; it, therefore, cannot be structurally collocational with "die". Semantic collocation, on the other hand, is a type of lexical cohesion which is occurrence relevance between two lexical items. The two lexical items are associated because of their frequent and semantic relevance to each other, as in "dog" and "bark".

Now, from the above discussion we can distinguish four types of composite units

\subsection{Open Collocation}

Cowie (1983) characterizes these as combination in which "both elements (verb and object or adjective and noun) are freely recombirable ... Typically, also, in open collocations, each element s used in a common literal sense" (X111). However, Bolinger (1968, pp. 6-7) reminds us of the semantic implications which constrain our choice of ostensible synonyms, for example:

45. They hurt her badly. (physical or material) VS. 46. They hurt her terribly. (sentiments, feelings)

47. I got my pants wet. VS. 48. I wet my pants.

An example of open collocations in Arabic:

49. bada?at /?intahat ?al-harab/?al-ma?rakah.

بدأت / انتهت الحرب / المعركة

(The war/battle began /ended.)

\subsection{Restricted Collocations}

Aisenstadt (1979) defines these as "combinations of two or more words used in one of their regular, non-idiomatic meanings, following certain structural patterns, and restricted in their commutability not only by grammatical and semantic valence, but also by usage" (p.71). For Cowie (1983) "in such combinations...one word... has a figurative sense not found outside that limited context" (VIII). This appears to contradict Aisenstadt but in fact the two views are compatible since, in a restricted collocation one of the elements may be either literal or figurative. In "explode"+"a myth/a belief" the verb is arguably figurative, while in "clench" + "one's teeth /fists" it is literal. The combination "clench one's teeth" could perhaps, be used in a wholly figurative way in the sense of grit one's teeth, in which case it would no longer be analyzed as a restricted collocation but as an idiom.

Cowie (1981) says the choice of the specialized meaning of the verb is contextually determined since "explode" in the sense "show to be false" or "no longer true" occurs in no lexical context other than that already shown (myth, belief) (p.227). For Curse (1986), collocations "have a kind of semantic cohesion-the constituent element are, to varying degrees, mutually selective" (p.40). In Arabic, as in English, this type of collocation occurs in various types of syntactic configuration.

\section{1). Subject/Verb}

50. birds chirp (fly, sing)

51. ?indala؟at/našabat/šabbat ?al-harb/?al-ma?raka

اندلعت /نثبت/شبت الحرب / المعركة 
(the war/battle broke out/flared up )

\section{2). Verb/Object}

52. compile a dictionary

53. launch a missile

54. reject an appeal

55. xāđa ?al-ma?raka/?al-mufāwađāt

خاض المعركة / المفوضات

(He rushed into/embarked on battle/negotiations.)

3). Adjective / Noun

56. grave concern

57. sincere condolences

58. ma؟raka/harb țāhinah/ša $؟_{w a ̄ ?}$ / đārriya

حرب طاحنة / شعو اء / ضاريه معركة /

(devastating /damaging war/battle)

59. jarīma/?ibtisāma nakrā?

جريمه / ابتسامه نكر اء

(vicious crime/smile)

The co-collocants in these example generally exhibit a certain similarity of meaning and collocations like "harb țāhina" (lit. grinding war) and "xāđa?al-mufāwađāt" (lit. plunge into negotiations) are arguably semantically motivated. Yet, in such figurative extension the direction and nature of the extension is language-specific and hence unpredictable. It is this interlingual incongruence which can give rise to second language learning difficulties and problems of translational equivalence.

\subsection{Bound Collocations}

This type of composite unit, described by Cowie (1981) as "a bridge category between collocations and idioms "exhibits unique contextual determination; in other words, one of the elements is uniquely selective of the other" (p.228). The selecting element is typically "specialized" in meaning. This type of collocation is relatively uncommon in English. Examples are:

60. foot the bill

61. carry favour

But Arabic's derivational richness frequently permits a particular pattern combination:

62. harb-un đarūs

حرب ضروس

fierce (murderous ) war

63. jayš-un jarrār-un

جيش جرار

huge (tremendous) army

In such cases the adjective collocates uniquely with a specific noun. The selecting item is not invariably figurative; in the following examples each non-figurative verb collocates uniquely with a particular body-part:

64. أطرق الر أس

?aţraq-a ?al-ra?s

He bowed his head.

65.

şammar-a sawā? idah -u

He bared his upper arms. 
Such verbs may come to encapsulate the meaning of the collocant, in which case the body-part may be omitted. The degree to which this occurs varies:

66. ațraqa (he bowed his head) but not

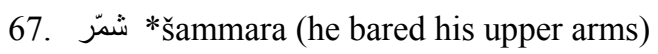

Bound collocations readily lend themselves to idiomatic use " "šammar-a ?al-saw?id” more commonly carries the meaning "get down to work".

\subsection{Idioms}

Contrary to the case in the previous types of composite unit, the constituent elements of idioms are opaque i.e. used in specialized senses, together forming a single semantic unit. Idioms have traditionally been divided into semantic and lexical, the latter type more commonly referred to compounds. In the latter type of structure, neither element preserves its literal meaning and the unit refers to a single specific referent. Illustrative examples are:

68. الحرب البارده

?al-harb-u ?al-bārida

the cold war

69. عرب الكو اكب / النجوم

Harb-u ?al-kawākib/?al-nujūm

(star war)

70. Kick the bucket.

71. Fly the handle.

72. Spill the beans

73. Red herring.

\section{Collocation in Arabic}

In Arabic little has been written about collocation. It is found in Arabic, though, under different titles as: التلازم

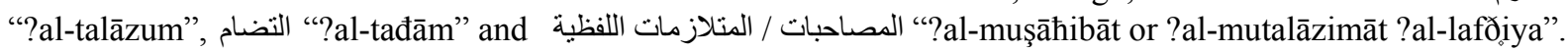

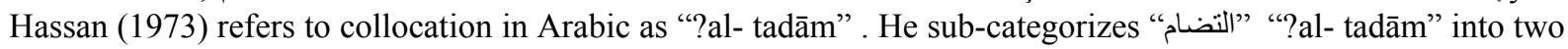

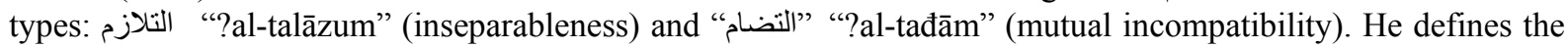
term "?al- tadām" as the habitual co-occurrence of two lexical items. The relation that binds between these two lexical items could be rhetorical or grammatical (p.217).

It is true that "'التلازم"?al-talāzum" is lexically much more compatible with "?al-tađām", however,

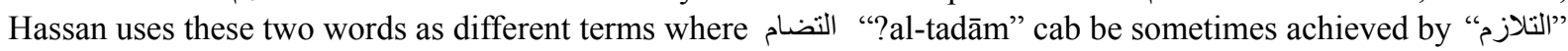
"?al-talāzum".

Hassan, adopting a classical view of collocation, establishes that collocational expressions or التنازي" "?al-talāzum" can be represented by two types: المبنى الوجودي?al-mabnā ?al-wujūdi (structural or existensial) and المودئنى al-mabnā ?al-?adami (referential). Examples of العبنى الوجدي ?al-mabnā ?al-wujūdi are: relative pronouns, noun of gentive construct, prepositional phrase, conjunctive expressions and demonstratives. Hassan refers to referential collocations where one lexical item is mentioned and the other is referred to and understood from the given context. Consider the examples:

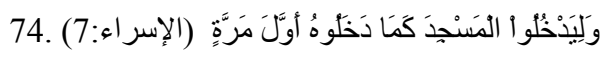

wal-ydxulū ?al-masjid-a kama daxalūhu ?awala marra.

And to enter your Temple as they had entered it before (Al-Isrā?, p.7)

The word المسجد ?al-masijid in the above example is related to "?al-masijid ?al-?aqsā" which is understood from the given context. Despite the fact that the word "?al-?aqşā" which collocates with "?al-masjid" is referred to in the context, they are still considered collocations.

\subsection{Types of Collocations}

Al-Qasimi (1979) adopts a more analytical view of collocations, thus, he argues that collocations in Arabic include the followings types: 
1. Noun - adjective

?al-waţan ?al-@arabi (The Arab Word)

?al-ta?āwun ?al- ?iqtişādi (Economic Cooperation)

2. Verb - preposition

?istafsara ?ann (to inquire about)

?iqtaraba min (came near to)

3. Adjectives -preposition

مرتبط بـ murtabiţ -un bi ( related to)

؟ عزيز على بazīz-un ؟alā (dear to)

4. Participle - preposition

?al-faŝal fì (failure in)

?al- sa?ay ?ilā (seeking for)

5. Nouns of genitive construct

أعضاء اللجان ?ådā? ?al-lijān (members of committees)

6. Conjunctive expression

?al-t؟āwun wal-ta؟āzur (assistance and cooperation)

7. Quantitative specifications

؟adad-un kabīrun min (a great number of)

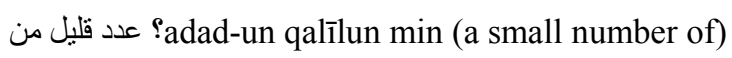

8. Qualitative specifications

?ila ћad-in ba?īd-in (to a large extent)

9. Locative expression

في في كل مكان

من هناو هناك

\subsection{Characteristics of Collocation}

Collocations can be characterized as follows.See Al-Qasimi (1979-29-30):

1. A collocation does not constitute a semantically or grammatical single indivisible unit.

2. The meaning of the collocation can be predicated from the meanings of the individual words themselves. The meaning of the collocation "المعاهدةخرق xaraq-a ?al-mu؟ahāda" can be predicated from the individual words to

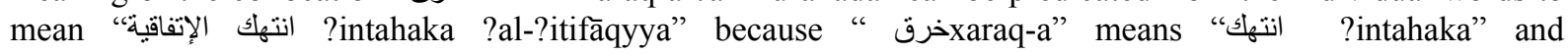

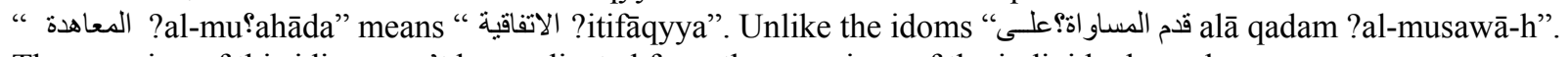
The meaning of this idiom can't be predicated from the meanings of the individual words.

3. According to Arabic syntax, one lexical item can be understood without referring to the other lexical unit. The word " سالقــ ?al-quds" can be understood without the other lexical item " الثريف "al-sarīf”.

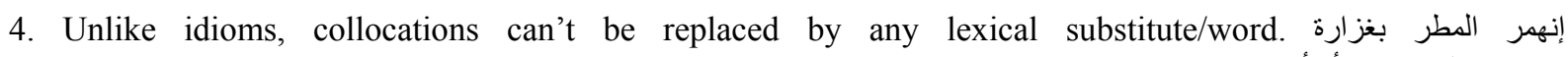

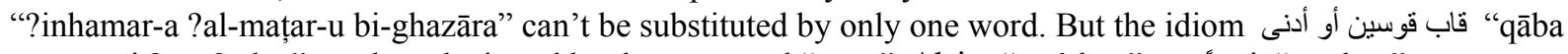
qawsayni ?aw ?adnā" can be substituted by the one word "soon" وشيكا "waŝîkan" or قريبا "qarīban".

5. Unlike idioms, collocations manipulate i.e. the individual lexical items can be substituted by similar words

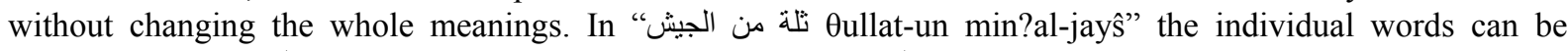

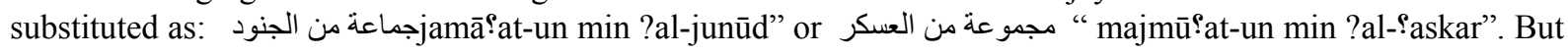

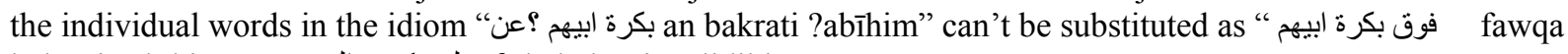
bakrati ?abīhim” or " "ع بلى بكرة والدهم "alā bakrati wālidihi”.

\subsection{Categories of Collocation}

El-Hasan (1982, p.276), in his study of collocation in Arabic, argues that lexical items that collocate fall into three categories: 


\subsubsection{Opposites}

75. الثرق و الغرب?al-ŝarq-u walgharb (the east and the west)

76. الحياة والثوب ?al-hayāt-u wal-mawt (life and death)

77. ?al-ka0ir-u wa-qalīl ( the abundant and the scarce)

78. al-?ậmā wal-başīr (the blind one and the one who can see)

79. الغنى و الفقير?al-ghaniya wal-faqiir ( the rich man and the poor man)

\subsubsection{Synonyms}

In this respect, the Holy Qur'an is rich in collocation of synonyms. This type of collocations is effective in serving to reinforce the message:

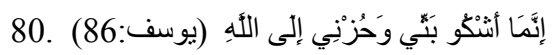

?innama ?aŝkū ba $\theta \theta \bar{i}$ wahuznī ?ilā ?al-lāh

I complain to Allah about my grief and sadness (Yusuf, p.86)

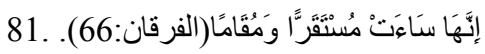

?innahā sā?at mustaqarr-an wa muqāmā

It (hell) is a bad place to settle in and live in (Al- Futqān, p.66)

El-Hassan explains that "ba $\theta \theta$ " is deep "huzun" in one sense, and in another "ba $\theta \theta$ " is grief which is expressed in words, while "huzun" remains unfolded in the heart.

\subsubsection{Complementariness}

This category may be illustrated by the following examples:

82. بالقول و العمل

bil-qawli wal-؟amal (by word and deed)

83. الر اديو والتلفزيون

?al-rādyu wal-talifizyōn (radio and television)

84. اعطني ورقة وقلم

?ậtinī waraqat-an wa qalam (Give me a piece of paper and a pen)

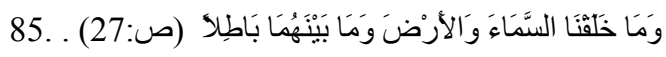

wamā xalaqna ?al-samamā?-a wal-?arđ-a wamā baynahuma bāțilā

We haven't created the sky (heaven) and the earth in vain (Şād, p.27).

Such collocations consist of conjoined pairs of lexical items comprising categories or phenomena with some strong semantics, spatial, temporal or functional link.

In his work (1990:35-37) El-Hasan handled "Collocational Distribution" maintaining that synonyms do not qualify for absolute synonymy because of differences in their collocational distribution. Consider the following

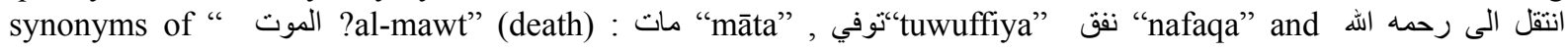
"?intaqala ?ilā raћmati ?allāh".

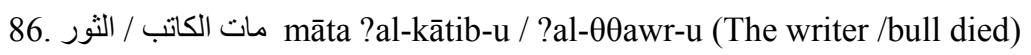

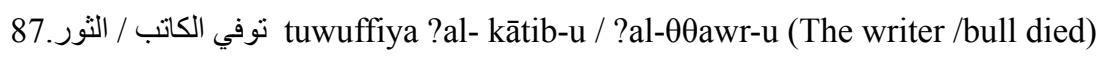

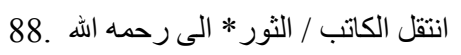

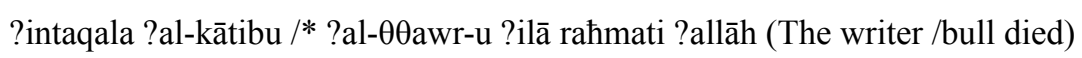

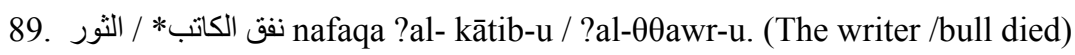

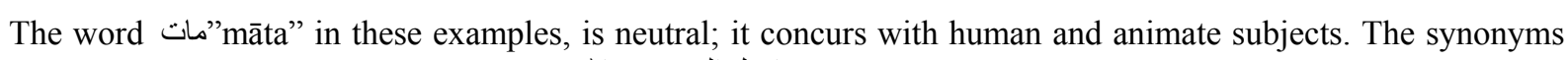

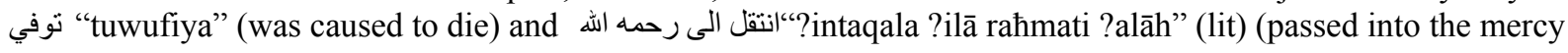
of Allah" can only be used where the recipient/suffers is human. Finally, the synonym نفع "nafaqa"(It died) does not collocate with human beings or plants; it requires a non-human, animate subject. Consider the following in support of the variability of collocational distribution of Arabic synonyms. The words بلس "jalsa" برك "baraka", and "jaقama" are synonymous as their meaning has to do with "act of sitting". However, every one of these 
synonyms has its own collocates. See Al- Tha'alibi (129). Thus جلس “jalasa” collocates with human subjects, برك "جل "baraka" is appropriate for camels, and جنم "jaقama" collocates with birds.

90. جلس المعلم

jalas-a ?al-mu؟allim-u

The teacher sat down.

91. برك الجمل

barak-a ?al-jamal-u

The camel knelt.

92. جثم العصفور

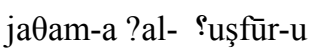

The sparrow perched.

Finally, Al-Aqtash (1994) concurs with Hassan (1973) in defining collocation as the habitual co-occurrence of two lexical items. However, Al-Aqtash argues about aspects a special type of collocation namely إطباق المزاوجه "?itbāq ?al- muzāwaja" where two or three lexical items co-occur and have the same rhyme as in:

93ayyn-un layyn-un (Nice and Easy)

haסir-un bāoir-un (Confused and Unsuccessful)

أخذ بحذافيره وجذاميره وجر اميزه.95

?axaða bihaðāfïrihi wajaðamīrihi wa jarāmīzihi (He took it entirely)

In the light of translating the above rhyming collocation, it is obvious that what might rhyme in Arabic might not rhyme in English, and vice-versa. Consider the following examples in English:

96. hoilty-toity سلوك مستهتر (sulūk-un mistahtir)

97. roly-poly قصير ممتلئ الجسم (qaşîr-un mumtali?u?al- jism)

98. hocus-pocus هراء (hurā?)

\subsubsection{Discussion: Similarities and Differences}

It is clear from the above-mentioned discussion that collocation in Arabic is not as exclusively discussed as it in English. It is also clear that although English and Arabic (unrelated languages) classify collocation into various categories, these categories are not always synonymous to each other. It has been noted that the exact equivalent for collocation in the target language has been one of the major problems for both students and teachers in learning/teaching process and for translators as well. Collocations as a problematic area may be restricted to lexical choice. Consider the following examples:

99. English is a famous language. for 100. English is a universal language.

101. He wants to grow his knowledge. for 102. He wants to develop / increase his knowledge.

This is probably due to: language specifics, interference of mother tongue i.e. transfer from the native language or lack of extensive reading of contemporary English and Arabic prose.

Yet, it seems that most linguists agree that:

1) Collocation of both languages refers to the habitual co-occurrence of individual lexical items. Examples from English are: "pay attention", "addled eggs", "pretty girl", and "fish and chips". Examples from Arabic are: الوطن

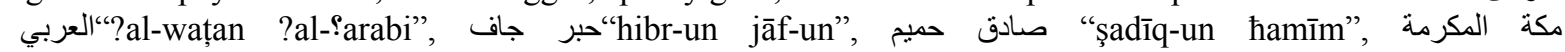
"makat-u ?al-mukarramat-u".

2) Collocations are a type of syntagamatic lexical relations e.g. adjectives+ noun as in: grave concern, "harb-un đarūs".

3) Collocations are linguistically predictable in both languages i.e. the tie between "spick" and "span" is stronger than that between "letter" and "piller box".

4) In both languages there are many totally predicted restrictions i.e. the occurrence of the items is frequent that their occurrence becomes predictable: "spick"+ "span" خلف الناقة "xilfu ?al-nāqa".

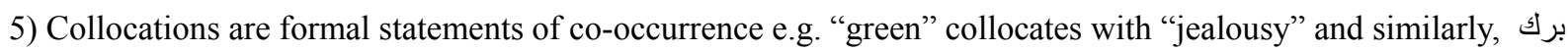
"barak-a", collocates with جمل "jamal". 
6) In both languages the verb of the collocation can be substituted. Examples: "to commit murder" and "to

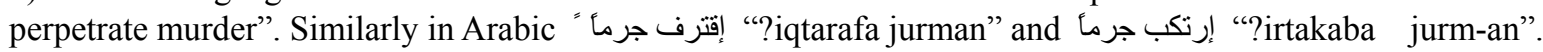

7) Association of ideas: Wherever you mention a collocate, the other collocate immediately jumps into your mind: "keen competition", "pitched battle", "receive warmly" and "war breaks out". حاك "ure

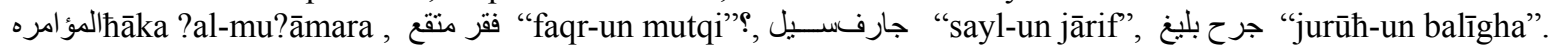

8) In both languages the lexemes are variable with other lexemes. The combination defines the meaning of the individual items. Examples from English: the adjective "heavy" has many meaning according to the collocates:

\begin{tabular}{|c|c|c|}
\hline 103. heavy rainfall & مطر غزير & mațar-un gha \\
\hline heavy fog & ضباب كثيف & dabāb-un kat \\
\hline heavy sleep & سبات عميق & subāt-un ؟an \\
\hline heavy sees & بحار هائجه & bihār-un h \\
\hline heavy meal & وجبة دسمه & wajjbat-uı \\
\hline heavy smoker & مدخن مفرط & mudaxin-un \\
\hline heavy industry & صناعة ثقيلة & şinā?at-un $\theta \mathrm{aq}$ \\
\hline \multicolumn{3}{|l|}{ Arabic examples are: } \\
\hline 104. ?istiqbāl-un jāa-un & إستقبال جاف & cool reception \\
\hline manāx-un jāf-un & مناخ جاف & dry weather \\
\hline qalam-u hibr-in jāf-in & قلم حبر جاف & a ball-point pen \\
\hline lahjat-un jāfat-un & لهجة جافة & harsh tone \\
\hline jild-un jāf-un & جلا جاف & rough skin \\
\hline
\end{tabular}

9) Collocational in both languages is not mere juxtaposition because it is mutual expectancy of two items or more. The two items can be separated in the sentence or they may occur in two separate sentences:

105. Integrated plan to provide sufficient workers according to local requirements should be devised.

106. يقوم المشرفون التربويون في وكالة الغوث الدوليه بنشاط ملحوظ

yaqūmu ?al-muŝrifūna ?al-tarbawiyūna fī wakalati ?al-ghaw $\theta$ i ?al- dawliyati bi-naŝațin malhūō.

10) Although the synonyms of the same semantic field have very near meanings, each has its own collocate. These collocates can't be predicted by foreigners.

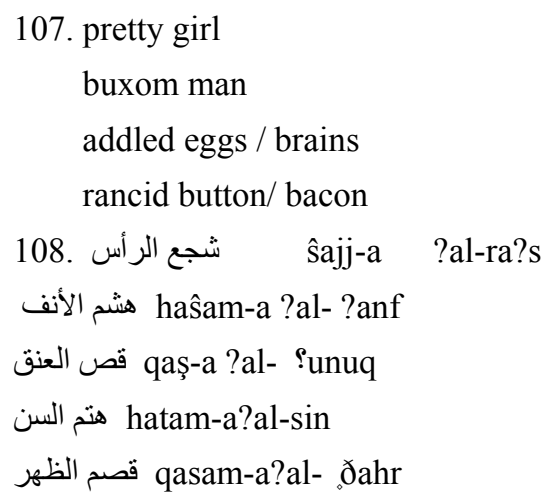

11) Some collocation in both languages die, others come into existence. Examples are:

109. senetic engineering

star war

noise, sound pollution

$$
\text { 110. ترشيد الإستهلاك } \quad \text { tarŝ̄id ?al-?istihlāk }
$$

al- hājiz ?al-nafsī

al-?amn ?al-ghiðā?̄i

12) Collocational range is not completely identical. Even if they are identical in their true meaning, they differ in 
their figurative meaning. The verb runs "jarā" in English and Arabic is used for humans, animals and transportations. But figuratively the collocates are not identical:

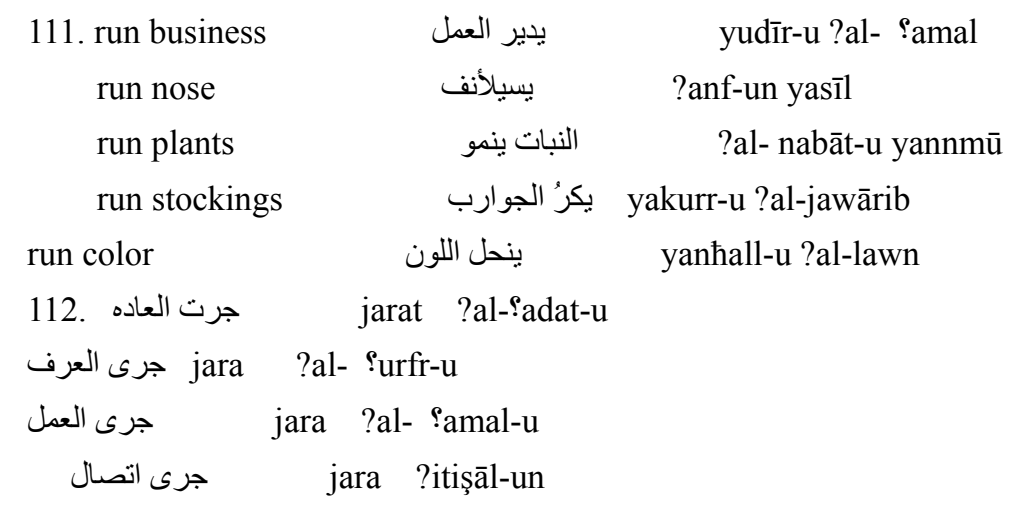

Now we have to notice the difference between English and Arabic: the most important difference between these two languages is cultural. The relation between language and culture is inseparable. Teachers, instructors and translators have to be aware of this relation between culture and language and the effects of this relation in teaching/learning process and translation. That is to say, different languages reflect different cultures. For example English reflects the culture of the Britons while Arabic language pertains to the Arabic-Islamic culture. Although such languages may reflect certain similarities, each is unique in its own right. Therefore, successful teachers, instructors and translators should be fully aware of both cultures. The followings are illustrative examples:

1. Certain terms which are cultural specific may give rise to translational difficulties. Consider the Arabic expression: مجلس قيادة الثورة "majlis qiyadat?al-Oawra” (the revolutionary command council). The phrase would sound alien to most English readers because it is not part of their culture. Therefore, we have to make such vague terms clear for English readers through adding the paraphrase "the highest executive body in the country".

2. The term دول صديقة وشقيقة "duwal-un şadīqat-un wa-ŝaqīqat-un” (sisterly and friendly countries) is not found in the west. That is to say, they don't divide the world countries into şadīqa (friendly) and saqīqa (sisterly). This division is only part of the Arabic culture and is used in reference to Arab countries.

Therefore, instructors should focus upon teaching vocabulary and multi-word units by giving students enough practice.

\section{Findings and Conclusion}

Collocation is a linguistic phenomenon in language whose influence may be more far-reaching than previously acknowledged. Both Greenbaum (1974, p.89) and Bolinger (1976, p.8) emphasis the major importance of collocational sized lexical units both in the early years of language acquisition and also in the continuing years of vocabulary development. This fact has implications for linguistic applications such as language teaching and translation. Advanced learners of English, according to the researcher's experience as a school supervisor of English, find greatest difficulty precisely in this area of language: students and even teachers make predominately lexical, stylistic and appropriateness errors. The needs of learners of English are now beginning to be catered for, but the problems of incorporating collocational information into bilingual dictionaries still pose formidable challenge.

Arabic, a language singularly rich in lexical and derivational resources, exhibit collocation in profusion. Classical lexicographers such as Tha?alibi and Ibn Sidah were keenly aware of the phenomenon and dictionaries of meanings such as figh ?al- lugha and ?al- muxaşşaş contain a wealth of collocational information. Unfortunately, the arrangement of the material is often idiosyncratic and unsystematic. Also, there is much that is obsolete and no longer relevant to Modern Standard Arabic. certain contemporary bilingual dictionaries such as Wehr (1979) note a certain amount of collocation information but not in the sort of systematic way which could assist learners of Arabic. Benson (1985) maintains that "Dictionaries should provide such collocations at the entry for the dominant word (verb, noun, or adjectives). The leading British learner's dictionaries. The Longman Dictionary of Contemporary English (LDOCE) and A. S. Hornby, Oxford Advanced Learners Dictionary of Current English (ALD)-do give a large number of grammatical collocations" (p.62). Apresyan, Mel'cuk, and Źolkovsky working originally in the Soviet Union, have made a significant contribution to the treatment of collocation. They proposed a new type of dictionary called the Explanatory and Combinatory Dictionary (ECD). The ECD method is to subject a relatively small number of carefully selected entries to a very detailed 
grammatical and lexical treatment. Each entry is arranged in exactly the same way and provides exactly the same type of information. The entry contains the definition, pertinent morphological and syntactic information, lexical functions, phraseology and a discussion of synonyms and near synonyms. The most significant innovation of the ECD is the concept of lexical functions. For more details see Benson (1985, pp. 62-63) and Apresyan et al. and Mel'ĉuk et al. As for up-to-date monolingual dictionaries of Arabic, they simply do not exist; see Zughoul (1980) Arabic needs work on its lexicography (p.212). There is no single modern efficient Arabic -Arabic dictionary anywhere in the Arab -world comparable in quality and ease of reference to Webster's for example." There is a pressing need for descriptive studies of contemporary Standard Arabic at various levels of language but especially the lexical, with particular attention to collocational usage, since it as at this level that Modern Standard Arabic differs most sharply from its classical precursor. Additionally, it could be safely stated that any language abounds collocation including synonymy, antonym, complementariness and idioms. Arabic and English serve as good examples. In addition, collocation have their own life cycle: They came and go, they are born and they die.

\section{Recommendations}

Although this research is linguistically descriptive and is not pedagogically oriented, it may have pedagogical implications for foreign language teachers, and students, (cf. Farqhal M. \& Obeidat, H., 1995) translators, text book writers, test makers and syllabus designers as well as lexicographers. That is to say theoretical contrastive analysis has pedagogical implications that can be useful for teachers and learners of foreign languages as well as for translators and syllabus designers. Moreover, the study may be helpful to ESP practitioners who are interested in preparing ESP teaching materials based on the analysis of authentic texts.

1. Teachers of foreign languages should receive intensive training on how to use and how to teach collocations.

2. Students of foreign languages, and interpreters should also be intensively trained on how to use collocations and to build own memory back of collocations.

3. Syllabus designers should take collocations into consideration through proposing suitable materials and programmers for teaching collocations in schools, community college, and universities.

4. Intensive studies for collocational phenomenon in L1 and L2 should come into existence.

5. Dictionary -makers should propose collocation - specialized monolingual and bilingual dictionaries.

\section{References}

Aisenstadt, E. E. (1979). Collocability Restriction in Dictionaries. ITL: Review of Applied Linguistics, 45, 71-74.

Aisenstadt, E. E. (1981). Restricted Collocations in English Lexicology and Lexicography. ITL, 53, 53-62.

Al-Agtash, A. (1994). Ittiba’ Al-lga' Fi Al-lugha Al-Arabiya. Abhath Al-Yarmouk (Vol. 12, pp. 121-177).

Allerton, D. J. (1984). Three (or Four) Levels of Word Co-occurrence Restriction. Lingua, 63, 17-40. http://dx.doi.org/10.1016/0024-3841(84)90030-5

Al-Qasimi, A. (1979). Al-Ta'abeer Al-Istilahiya wa-Siyagiha Al-LisanAl-Arabi. Al-Ribat-Moroco.

Al-Tha'alilbi, A. A. M. Figh Al-Lughah wa Asrar Al-Arabiyya. Cairo: Matba'at Al-Istiqlal.

Benson, M. (1985). A Combinatory Dictionary of English, 7, 189-210.

Benson, M. (1986). Collocations and Idioms. In R. F. Ilson (ed.), EIT Documents 120: Dictionaries 120: Dictionaries. Lexicography and Language Learning. Oxford: Pergamon.

Bolinger, D. (1968). Aspects of Language. Harcourt Brace Jovanvich Inc. USA.

Bolinger, D. (1976). Meaning and Memory. Forum Linguisticum I, 1-14.

Cowie, A. P. (1981). The Treatment of Collocations and Idioms in Learner Dictionaries. Applied Linguistics, 2, 223-235. http://dx.doi.org/10.1093/applin/2.3.223

Cruse, D. A. (1986). Lexical Semantics. Cambridge: Cambridge University Press.

El-Hasan, S. (1982). Meaning by Collocation with Illustration from Written Arabic. Arab Journal for Humanities, 2(8), 269-281. Kuwait University.

El-Hasan, S. (1990). Synonymy and Its Distribution in Arabic. Abhath Al-Yarmouk, 1, 23-43. Yarmouk University.

Fakhouri, S. (1995). Collocation in Interpretation from English and Arabic [M. A. Thesis]. Yarmouk University-Jordan. 
Farghal, M., \& Obediat, H. (1995). Collocation: A Neglected Variable. EFL.IRAI, 33(4), 315-331.

Firth, J. R. (1957). A Synopsis of Linguistic Theory. In Palmer, E. R. (ed.), Selected Papers of J. R. Firth 1952-59. London: Longman.

Firth, J. R., \& Palmer, F. R. (1968). Selected Papers of J. R. Firth 1952-59. California: Indiana University Press.

Halliday, M. A. K. (1966). Lexis as a Linguistic Level. In E. C. Bazell et al. (eds.), In the Memory of J. R. Firth. London: Longman.

Hassan, T. (1973). Al-Lughatu Al-Arabiya-Ma'naha wa-Mabnaha Al-Hay’a Al-Misriya Al-Amma Lil-Kitab.

Hill, J. (1990). Collocational Competence. ETP, 11.

Kats, J., \& Foder, J. A. (1963). The Structure of a Semantic Theory. Language, 39, 170-210. http://dx.doi.org/10.2307/411200

Lehrer, A. (1974). Semantics Field and Lexical Structure. Amsterdam: North Holland Publishing Co.

Lyons, J. (1968). Introduction to Theoretical Linguistics. London and New York: Cambridge University Press. http://dx.doi.org/10.1017/CBO9781139165570

Mitchell, T. F. (1975). Linguistic "Going-on": Collocations and Other Lexical Matters Arising on the Syntagamatic Record. In J. R. Firth, Principles of Firthian Linguistics. London: Longman.

Newmark. (1981). Approaches to Translation. Oxford: Pergamon.

Newmark. (1988). A Textbook of Translation. Great Britain: A.Wheaton and Co LTD Exeter.

Nida, E. A. (1964). Towards a Science of Translating. Leiden: Brill.

Obana, Y. (1993). The Linguistic Significant of Lexical Items. META, 38(3), 491-501. http://dx.doi.org/10.7202/003752ar

Palmer, F. R. (1981). Semantics. Cambridge: Cambridge University.

Robins, R. (1964). General Linguistics: An Introductory Servey. Longman.

Williams, B. (2005). Collocation with Advanced Levels. Retrieved from www.Technqenglish.org.UK/think/vocabulary/collocation 1.html

Zughoul, M. (1991). Lexical Choices: Towards Writing Problematic Word Lists. IRAL, 29, 45-57. 


\section{Appendix}

Table 1. Phonetic Symbols of Arabic Consonants

\begin{tabular}{|c|c|c|c|}
\hline \multicolumn{2}{|c|}{ Transliteration } & \multirow[t]{2}{*}{ Phonetic Description } & \multirow[t]{2}{*}{ Arabic Examples } \\
\hline Arabic Letters & Symbol & & \\
\hline 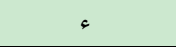 & $?$ & glottal stop & ?amal (hope) \\
\hline ب & $\mathrm{b}$ & voiced bilabial stop & balad (country) \\
\hline$ت$ & $\mathrm{t}$ & voiceless denti- alveolar stop & tammūz (july) \\
\hline$ث$ & $\theta$ & voiceless dental fricative & $\Theta u l u \theta$ ( one third) \\
\hline ج & $\mathrm{J}$ & voiced palato-alveolar fricative & jabal (mountain) \\
\hline$\tau$ & $\hbar$ & voiceless pharyngeal fricative & hubūr (joy) \\
\hline$\dot{\tau}$ & $\mathrm{x}$ & voiceless uvular fricative & xabīr (expert) \\
\hline د & d & voiced denti-alveolar stop & da؟awa(invitation) \\
\hline$\dot{~}$ & ð & voiced dental fricative & ðahab(gold) \\
\hline ر & $\mathrm{r}$ & alveolar trill /tap & rāya(flag) \\
\hline j & $\mathrm{z}$ & voiced denti-alveolar fricative & zirā؟a (agriculture) \\
\hline 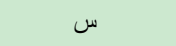 & $\mathrm{s}$ & voiceless denti-alveolar fricative & sabab (reason) \\
\hline 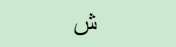 & $\hat{\mathrm{s}}$ & voiceless palato-alveolar fricative & sahīd ( martyr) \\
\hline ص & ş & voiceless alveolar fricative (emphatic) & şawāb(correct) \\
\hline 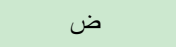 & đ & voiced denti-alveolar stop(emphatic) & đa!f (weakness) \\
\hline b & ț & voiceless denti-alveolar stop (emphatic) & țabīb( physician) \\
\hline ظ & ¡ & voiced interdental fricative (emphatic) & „ðulm (injustice) \\
\hline$\varepsilon$ & $\stackrel{\varphi}{9}$ & voiced pharyngeal fricative & ؟abīr (perfume) \\
\hline$\dot{\varepsilon}$ & gh & voiced uvular fricative & ghibța (delight) \\
\hline ف & f & voiceless labio-dental fricative & fasāha (fluency) \\
\hline ق & q & voiceless uvular stop & qamūs ( dictionary) \\
\hline ك & $\mathrm{k}$ & voiceless velar stop & kabīra (sin) \\
\hline J & 1 & lateral alveolar & luxa (language) \\
\hline s & $\mathrm{m}$ & bilabial nasal & murjān (pearls) \\
\hline ن & $\mathrm{n}$ & alveolar nasal & najāh (success) \\
\hline$\rightarrow$ & $\mathrm{h}$ & glottal fricative & ;;'l,,k,mkk,kioklhujūm (attack) \\
\hline
\end{tabular}

Table 2. Phonetic Symbols of Arabic Vowels

\begin{tabular}{|c|c|c|c|}
\hline \multicolumn{2}{|c|}{ Transliteration } & \multirow{2}{*}{$\begin{array}{c}\text { Phonetic description } \\
\text { Short front half-open unrounded }\end{array}$} & \multirow{2}{*}{$\begin{array}{c}\text { Arabic Examples } \\
\text { dam (blood) }\end{array}$} \\
\hline- & a & & \\
\hline$=$ & $\mathrm{i}$ & Short front open spread & ribāt (ribbon) \\
\hline$\therefore$ & $\mathrm{u}$ & Short front close rounded & mujīir (protector) \\
\hline 1 & $\overline{\mathrm{a}}$ & Long front open unrounded & şābir (patient) \\
\hline ى & $\overline{1}$ & Long front close unrounded & faqīr (poor) \\
\hline g & $\overline{\mathrm{u}}$ & Long front close rounded & waqūr (dignified) \\
\hline وَ & $\mathrm{w}$ & non-syllabic labio-dental semi-vowel & waşf (description) \\
\hline ن & $\mathrm{y}$ & on-syllabic palatal semi vowel & yaqīn (certainty) \\
\hline
\end{tabular}

Transliteration:

1. There is a linguistic rule that must be considered in the transliteration of the Arabic examples. The rule says that /1/ sound in the Arabic definite article /?al/ assimilates completely with the immediately following coronal consonant. This assimilation results in the doubling (geminating) of the coronal consonant: cf.?al- rajul (the man)?arrajul .Coronal consonant with which /I/ sound assimilates are called by Arab linguists sun letters; whereas the non-coronal consonants, which are not susceptible to germination are called moon letters. The moon 
letters are b, j, h, x, ؟, f, g, h, q, k, l, m, h, w, y.

2. The conjunctive hamza has been ignored in this study and disjunctive hamza is phonetically realized.

Definition of Terms:

damma /u/:the nominative marker of all definite singulars and the definite sound feminine plural:

1. ?al- walad-u(the boy) nom.

?al-wālidāt-u (the mothers) nom.

fatha /a/: the accusative marker of all definite singulars, e.g.

2. ?al-walad-a (the boy) acc.

kasra /i/: genitive marker of all definite singulars and the definite sound feminine plural:

3. ?al-wālidāt - i (the mothers) acc.and gen.

?al-walad - i (the boy) gen.

tanwin ( nunation): It is the process of doubling the final vowel case marker, the damma $/ \mathrm{u} /$ for the nominative case, the fatha /a/ for the accusative case, or the kasra /i/ for genitive and dative case. When the three case vowel markers are doubled at the end of a word, - un, - an, - in, they represent the three case endings, nominative, accusative and genitive. The 2 nd vowel is changed to $/ \mathrm{n} /$ :

4. şadīq-un (nom.) a friend

şadīq -an (acc.) a friend

şadīq -in (gen.) a friend 